\title{
Editorial
}

\section{$\beta$-cell Heterogeneity: The Key to $\beta$-cell Replacement Therapy}

\author{
Ercument Dirice, PhD* \\ Islet Cell and Regenerative Biology, Joslin Diabetes Center, Boston, MA, USA
}

\section{"Corresponding author}

Ercument Dirice, PhD

Research Associate, Joslin Diabetes Center-Instructor, Harvard Medical School, Boston, MA, USA; E-mail: ercument.dirice@joslin.harvard.edu

\section{Article information}

Received: August 20 $0^{\text {th }}, 2018$; Accepted: September $7^{\text {th }}, 2018$; Published: September $7^{\text {th }}, 2018$

\section{Cite this article}

Dirice E. B-cell heterogeneity:The key to B-cell replacement therapy. Pancreas Open J. 2018; 2(I): el0-el I. doi: I0.I7।40/POJ-2-e009

"It is not the strongest of the species that survives, nor the most intelligent that survives. It is the one that is most adaptable to change" (Charles Darwin The Origin of Species, 1859)

$\mathrm{C}$ ellular heterogeneity is crucial for organisms to adapt to their environmental changes. It provides the morphological, functional and molecular diversity that allows tissues and organs to respond to stressors and maintain cell integrity.

Pancreatic islets of Langerhans are cell clusters that play a key role in glucose homeostasis. Among the five hormone secretingislet endocrine cells (insulin secreting $\beta$-cells, glucagon secreting $\alpha$-cells, somatostatin secreting $\delta$-cells, pancreatic polypeptide secreting PP-cells, and ghrelin secreting $\varepsilon$-cells), $\beta$-cells are specialized glucose sensors that respond to increased insulin demand during physiological (i.e. pregnancy) or pathophysiological (i.e. type 2 diabetes) conditions. ${ }^{1-3}$

Since the 1960s, rodent and human studies have shown that seemingly identical $\beta$-cells can be grouped into morphological and functional subtypes. ${ }^{4-8}$ For instance, a recent study in mice reported that proliferative and mature $\beta$-cells can be distinguished by their expression of Flattop. ${ }^{9}$ Another study in mice, grouped a minor $\beta$-cell population (1-10\%) as hub cells being different from non-hub (follower) cells by their electrical-coupling capacity resulting in an organized insulin secretion. ${ }^{10}$ Understanding the mechanisms behind $\beta$-cell heterogeneity within or between islets can also be used as a therapeutic approach for $\beta$-cell survival. Indeed, a group of novel $\beta$-cells with lower granularity and stem-like feature has been reported to be protected during type 1 diabetes development. ${ }^{11}$

In parallel to rodent studies, several groups identified human $\beta$-cell subtypes by using technological advances. For instance, by using CyTOF to study at a single cell level, $\beta$-cells from multiple donors were grouped into three main populations based on their proliferation, maturation and several reported heterogeneity markers. ${ }^{12}$ On the other hand, Dorrell et al identified four distinct $\beta$-cell subpopulations based on their cell surface markers (CD9 and ST8SA1) which were developed by the same group. ${ }^{13}$

Nevertheless, the exact landscape of $\beta$-cell heterogeneity, including its functional and molecular significance, is incompletely understood.

Since type 1 (T1D) and type 2 diabetes (T2D) is marked by insufficient functional $\beta$-cell mass, there has been an increasing effort to develop $\beta$-cell replacement therapies. A promising strategy is to stimulate $\beta$-cell proliferation through small molecules, such as DYRK1A and TGF- $\beta 1$ inhibitors. ${ }^{14-16}$ Moreover, important advancements have been made to generate $\beta$-cells from other cell lineages, such as other pancreatic islet cells, pancreatic duct cells, and stem cells. ${ }^{17-19}$ However, understanding $\beta$-cell heterogeneity will be paramount to strengthening these approaches. Specifically, identifying and expanding $\beta$-cell subpopulations that are resistant to exogenous stressors (immune cells, high glucose, etc.) or primed for proliferation can provide a long-lasting therapeutic effect for T1D and T2D. To this end, several questions have yet to be answered:

1) What are the factors that influence heterogeneity of $\beta$-cells?

2) What is the origin of $\beta$-cell heterogeneity?

3) Does $\beta$-cell heterogeneity exist within islets or between islets or both?

4) How similar are $\beta$-cell subpopulations between rodents and humans?

5) Are specific $\beta$-cell subpopulations protected from stressmediated cell death in T1D and T2D? 
While recent studies have increased our understanding of $\beta$-cell heterogeneity, we need to further harness technological advances and smart study designs to characterize and exploit $\beta$-cell heterogeneity in therapies for T1D and T2D.

\section{CONFLICTS OF INTEREST}

None.

\section{REFERENCES}

1. Butler AE, Cao-Minh L, Galasso R, et al. Adaptive changes in pancreatic beta cell fractional area and beta cell turnover in human pregnancy. Diabetologia. 2010; 53(10): 2167-2176. doi: 10.1007/ s00125-010-1809-6

2. Rieck S, Kaestner KH. Expansion of beta-cell mass in response to pregnancy. Trends Endocrinol Metab. 2010; 21(3): 151-158. doi: 10.1016/j.tem.2009.11.001

3. El Ouaamari A, Dirice E, Gedeon N, et al. Serpin B1 promotes pancreatic beta cell proliferation. Cell Metab. 2016; 23(1): 194-205. doi: 10.1016/j.cmet.2015.12.001

4. Hellerstrom C, Petersson B, Hellman B. Some properties of the $\mathrm{B}$ cells in the islet of Langerhans studied with regard to the position of the cells. Acta Endocrinol (Copenh). 1960; 34: 449-456. doi: 10.1530/acta.0.XXXIV0449

5. Salomon D, Meda P. Heterogeneity and contact-dependent regulation of hormone secretion by individual B cells. Exp Cell Res. 1986; 162(2): 507-520.

6. Avrahami D, Klochendler A, Dor Y, Glaser B. Beta cell heterogeneity: An evolving concept. Diabetologia. 2017; 60(8): 1363-1369. doi: 10.1007/s00125-017-4326-z

7. Gutierrez GD, Gromada J, Sussel L. Heterogeneity of the pancreatic beta cell. Front Genet. 2017; 8-22. doi: 10.3389/ fgene.2017.00022

8. Liu JS, Hebrok M. All mixed up: defining roles for beta-cell subtypes in mature islets. Genes Dev. 2017; 31(3): 228-240. doi: $10.1101 /$ gad.294389.116
9. Bader E, Migliorini A, Gegg M, et al. Identification of proliferative and mature beta-cells in the islets of Langerhans. Nature. 2016; 535(7612): 430-434. doi: 10.1038/nature18624

10. Johnston NR, Mitchell RK, Haythorne E, et al. Beta cell hubs dictate pancreatic islet responses to glucose. Cell Metab. 2016; 24(3): 389-401. doi: 10.1016/j.cmet.2016.06.020

11. Rui J, Deng S, Arazi A, Perdigoto AL, Liu Z, Herold KC. Beta cells that resist immunological attack develop during progression of autoimmune diabetes in NOD mice. Cell Metab. 2017; 25(3): 727-738. doi: 10.1016/j.cmet.2017.01.005

12. Wang YJ, Golson ML, Schug J, et al. Single-cell mass cytometry analysis of the human endocrine pancreas. Cell Metab. 2016; 24(4): 616-626. doi: 10.1016/j.cmet.2016.09.007

13. Dorrell C, Schug J, Canaday PS, et al. Human islets contain four distinct subtypes of beta cells. Nat Commun. 2016; 7:11756. doi: 10.1038/ncomms11756

14. Wang P, Alvarez-Perez JC, Felsenfeld DP, et al. A high-throughput chemical screen reveals that harmine-mediated inhibition of DYRK1A increases human pancreatic beta cell replication. Nat Med. 2015; 21(4): 383-388. doi: 10.1038/nm.3820

15. Dirice E, Walpita D, Vetere A, et al. Inhibition of DYRK1A stimulates human beta-cell proliferation. Diabetes. 2016; 65(6): 1660-1671. doi: 10.2337/db15-1127

16. Dhawan S, Dirice E, Kulkarni RN, Bhushan A. Inhibition of TGF-beta signaling promotes human pancreatic beta-cell replication. Diabetes. 2016; 65(5): 1208-1218. doi: 10.2337/db15-1331

17. Bonner-Weir S, Inada A, Yatoh S, et al. Transdifferentiation of pancreatic ductal cells to endocrine beta-cells. Biochem Soc Trans. 2008; 36(Pt 3):353-356. doi: 10.1042/BST0360353

18. Pagliuca FW, Millman JR, Gurtler M, et al. Generation of functional human pancreatic beta cells in vitro. Cell. 2014; 159(2): 428439. doi: 10.1016/j.cell.2014.09.040

19. Xiao X, Guo P, Shiota C, et al. Endogenous reprogramming of alpha cells into beta cells, induced by viral gene therapy, reverses autoimmune diabetes. Cell Stem Cell. 2018; 22(1): 78-90. doi: 10.1016/j.stem.2017.11.020 